\title{
Avaliação da Ação Antibacteriana de Extrato de Trichilia catigua Contra as Bactérias Patogênicas de Origem Alimentar
}

\author{
Sara Gonçalves Paschoal (I), Erick Kenji Nishio (I), Gerson \\ Nakazato (I), Renata Katsuko Takayama Kobayashi (I), João Carlos \\ Palazzo de Mello (II), leda Spacino Scarminio (I), Audrey Alesandra \\ Stinghen Garcia Lonni (I) \\ (I) UEL - Universidade Estadual de Londrina (Rod Celso Garcia Cid Pr445 Km380 Cx Postal \\ 10011 Londrina PR), (II) UEM - Universidade Estadual de Maringá (Av. Colombo, 5790 - Jd \\ Universitário, Maringá-PR, BR. CEP 87020900)
}

\section{Resumo}

Recentemente tem sido relatada a resistência bacteriana a diversos antibacterianos, incluindo os micro-organismos de origem alimentar. Como alternativa no controle destes, o efeito antimicrobiano de produtos naturais tem sido estudado. Trichilia catigua, popularmente conhecida como catuaba ou catigua, é uma planta nativa que cresce abundantemente em várias regiões do Brasil. Tem sido usada na medicina popular para o tratamento de impotência, fadiga, stress e déficit de memória. Além disso, apresenta de acordo com a literatura atividade anti-inflamatória e antimicrobiana. Diversas bactérias estão envolvidas em distúrbios alimentares, dentre as quais destacamos: Staphylococcus aureus, Escherichia coli, e Bacillus cereus. O objetivo desse estudo foi avaliar a atividade antibacteriana do extrato de $\mathrm{T}$. catigua contra as principais bactérias responsáveis por distúrbios alimentares. Os extratos foram obtidos através do planejamento experimental Centróide Simplex envolvendo os solventes água, metanol, acetona e etanol, que gerou quinze extratos brutos de T. catigua (ETC). Para a avaliação da atividade antibacteriana foram utilizadas as seguintes técnicas: disco-difusão em ágar (antibiograma), determinação da concentração inibitória mínima (CIM), e

\footnotetext{
Referência:

Sara Gonçalves Paschoal, Erick Kenji Nishio, Gerson Nakazato, Renata Katsuko Takayama Kobayashi, João Carlos Palazzo de Mello, leda Spacino Scarminio, Audrey Alesandra Stinghen Garcia Lonni. Avaliação da Ação Antibacteriana de Extrato de Trichilia catigua Contra as Bactérias Patogênicas de Origem Alimentar. In: Anais do 12을 Congresso Latinoamericano de Microbiologia e Higiene de Alimentos - MICROAL 2014 [= Blucher Food Science Proceedings, num.1, vol.1]. São Paulo: Editora Blucher, 2014. 
curva de morte e crescimento com contagem de unidades formadoras de colônias (UFC). De acordo com os resultados do antibiograma os extratos 1 (água), 2 (metanol), 3 (acetona) e 4 (etanol) apresentaram halos de inibição para S. aureus ( $9 \mathrm{~mm}, 9 \mathrm{~mm}, 10 \mathrm{~mm}, 10 \mathrm{~mm}$, respectivamente). Para outras cepas bacterianas estes extratos não apresentaram efeito antibacteriano. A CIM dos extratos variaram entre 250 a $1000 \mu \mathrm{g} / \mathrm{mL}$. O extrato $1(1000$ $\mu \mathrm{g} / \mathrm{mL}$ ) eliminou toda a população bacteriana em apenas 7 horas de incubação, e em 5 horas de incubação, o número de UFC sob ação do extrato 1 foi 2160 vezes menor em relação ao controle (sem o extrato). Os nossos resultados mostraram potencial ação antibacteriana do ETC contra cepas de S. aureus, uma vez que, essa bactéria tem como reservatório primário humanos e animais, e está frequentemente associada a contaminação de leites e produtos lácteos. Portanto, o ETC poderia ser utilizado como um antimicrobiano natural.

Palavras-Chave: Atividade antibacteriana, Trichilia catigua, Catuaba Agência de Fomento: CNPq, UEL 